\title{
Economic features of investment nature of energy-saving projects in Russia
}

\author{
Olga Kalinina ${ }^{1, *}$, Vasilii Buniak $^{2}$, Galina Golubnichaya ${ }^{3}$, and Irina Kapustina ${ }^{4}$ \\ ${ }^{1,4}$ Peter the Great St. Petersburg Polytechnic University, Polytechnicheskaya, 29, 195251, St. Peters- \\ burg, Russian Federation \\ ${ }^{2,3}$ Financial University under the Government of the Russian Federation (Moscow) St.Petersburg \\ branch, 15-17 Sheshinskaya Str., Saint-Petersburg, 197198, Russian Federation
}

\begin{abstract}
This article studies conceptual approaches to the definition of investments in energy saving sector, considers economic features of such investments, and highlights financial aspects making the investments attractive to modern enterprises. The features of energy saving projects' investment analysis are considered, a model for calculating the payback of such projects at the expense of price or tariff is provided. To improve investments in energy saving sector, division of the process participants into economic entities and state bodies was proposed with separate recommendations provided for each of these groups.
\end{abstract}

\section{Introduction}

The most important task of modern world economy is to eliminate connection between economic development and environmental degradation due to consumption, use of energy and natural resources as well as waste generation. It is impossible to make a person to consume less goods or services in modern society. Russia has not yet reached the level of energy resources consumption as, for example, European countries or the USA show. In this connection consumption level will inevitably rise (as well as energy production). In order to avoid global environmental crisis, goods and services consumption and production patterns have to be changed at a qualitative level in the context of the new digital economy, which practical problems are considered in the concept of the sharing economy by I. Alexandrov and M. Fedorova [1-6]. Some interesting ideas about energy-saving project are considered by famous scientists in several fields of the researches in innovation projects [7-9]. The solar panel transport tunnel magnetic levitation is studied in [4].

The concept of sustainable development and digital economy does not imply refusal from consumption and industrial production, as it is impossible to meet the basic needs for self-realization of every human being. On the contrary, the concept will contribute to raising social standards of quality of life, provided that there is a shift from quantitative consumption to a better quality consumption. The sustainable consumption and production model is based on a systematic approach to product lifecycle management and addresses

*olgakalinina@bk.ru 
2

several key issues: to meet the needs of every person, to improve quality of life of society, to improve efficiency of resources use, to minimize waste generation, to use alternative fuels and renewable energy sources. Investments are required to address all these issues.

\section{Materials and Methods}

Investing in energy-saving technologies establishes the framework for stable operation of an organization with any type of economic activity. Let's represent the composition of investment in energy-saving technologies industry-wise (Table 1):

Table 1. Composition of investment in energy-saving technologies in the Russian Federation industry (wise in years 2014-2018), \% [Source: https://www.minenergo.gov.ru]

\begin{tabular}{|c|c|c|c|c|c|}
\hline Industry & $\mathbf{2 0 1 4}$ & $\mathbf{2 0 1 5}$ & $\mathbf{2 0 1 6}$ & $\mathbf{2 0 1 7}$ & $\mathbf{2 0 1 8}$ \\
\hline $\begin{array}{c}\text { Agriculture, hunt- } \\
\text { ing and forestry }\end{array}$ & 2.36 & 2.69 & 3.10 & 3.30 & 3.40 \\
\hline Mining operations & 31.43 & 42.91 & 55.43 & 50.46 & 51.23 \\
\hline $\begin{array}{c}\text { Manufacturing in- } \\
\text { dustries }\end{array}$ & 14.18 & 10.55 & 7.38 & 10.75 & 13.44 \\
\hline $\begin{array}{c}\text { Generation and } \\
\text { distribution of elec- } \\
\text { tricity, gas and water }\end{array}$ & 9.32 & 11.70 & 14.40 & 9.33 & 10.96 \\
\hline $\begin{array}{c}\text { Construction } \\
\text { Wholesale and re- } \\
\text { tail trade; vehicle } \\
\text { repair }\end{array}$ & 4.05 & 2.85 & 1.78 & 2.02 & 1.56 \\
\hline $\begin{array}{c}\text { Hotels and restau- } \\
\text { rants }\end{array}$ & 0.43 & 0.49 & 0.57 & 0.61 & 0.64 \\
\hline $\begin{array}{c}\text { Transport and } \\
\text { communications }\end{array}$ & 3.58 & 2.75 & 2.05 & 1.26 & 1.17 \\
\hline \begin{tabular}{c} 
Financial activities \\
\hline $\begin{array}{c}\text { Real estate opera- } \\
\text { tions, rental and pro- } \\
\text { vision of services }\end{array}$
\end{tabular} & 2.42 & 2.64 & 2.94 & 3.06 & 3.09 \\
\hline $\begin{array}{c}\text { Other industries } \\
\text { Total }\end{array}$ & 22.98 & 13.48 & 1.44 & 8.70 & 3.95 \\
\hline & 100.00 & 100.00 & 100.00 & 100.00 & 100.00 \\
\hline
\end{tabular}

Thus, in 2014 investments in energy saving in the extractive industry prevailed (31.43\%), in 2018 this amount increased significantly and the share of investments in this industry reached $51.23 \%$. This partly resulted from the need of many mining companies to replace their power equipment. The manufacturing industry also occupied a significant relative share $-14.18 \%$ in 2014 and $13.44 \%$ in 2018 . 
The analysis of energy consumption statistics and investment in energy saving technologies in Russia for the period from year 2014 to year 2018 showed that, despite the improvement of most indicators in absolute terms, there are a number of factors limiting the investment activities of enterprises in the field of energy-saving technologies. These factors include:

1) lack of availability of borrowed resources for such projects;

2) general investment risks associated with the implementation of investment projects in the field of energy saving;

3) immaturity of the regulatory, legal and methodological framework governing the investment activities of organizations in the field of energy saving.

Analysis of recent sources and publications devoted to investments in order to improve energy efficiency showed that scientists give considerable attention to the topic. There is also a number of publications specifically devoted to the analysis of efficiency of investments in energy saving projects [3-4].

Investment in energy saving technologies could be considered as part of the national investment process. Investment into energy saving sector is an investment that is carried out within the entire national economic complex and takes into account environmental tasks and priorities.

At the same time, the term "environment-oriented investments" was introduced and defined as all types of values invested by an investor (property, financial and intellectual assets) aimed at reducing and eliminating inefficient energy resources consumption, conservation, improvement and optimal use of the natural resource potential of the territories as well as formation of the country's ecological safety, as a result of which ecological, social, economic and political goals can be achieved.

E. Cagno, E. Worrell, A. Trianni and G. Pugliese believe that any investment, regardless of the object of its investment, can be characterized as having a certain environmental impact and environmental effect, as any production impacts the environment [5]. The said environmental effect is the essence of environmental performance of investment in information technologies and energy-saving sectors. It causes changes in the environment, and affects both internal and external actors of the investment process [5].

The following definition could be given: "investment in energy saving technologies is a task-oriented process of economy's transformation aimed at reducing the integral ecodestructive impact of goods and services production and consumption processes per unit of the total social product with the use of digital technologies. It is carried out through a system of organizational measures, innovation processes, restructuring of production as well as consumer demand, technological conversion using digital technologies, which are implemented at both the macro- and microeconomic levels."

Some scientists limit investments in energy saving sector by investments to environment protection, investments in environment recovery and (or) restoration, decreasing pollution levels for existing and newly established enterprises. At the same time the term "environmental investments" could be applied.

It's important to note that some scientists strongly disagree to identify the terms "environmental investments" and "energy-saving investments" as equal terms, explaining that energy saving goes far beyond the concept of ecology. Scientists argue that the latter can be considered as part of the transformation processes of the national economic complex, which 
4

qualify as energy saving. Thus, while energy saving concept includes environmental management processes, it has conceptual differences.

One of the innovative approaches to determine the essense of investments in energy saving technologies is to separate them into an independent tool of the enterprise environmental management system and national energy policy. K. Soremann gives the following definition: "energy-saving investment is a consistent set of management actions by the relevant state bodies, investors and economic entities on the formation and use of environmental investments, which, first of all, provide for identifying the volume and optimization of the structure of funds for natural resources users, natural areas and regions of the country to achieve strategic goals to improve energy efficiency and environmental safety [1].

The energy saving investment is one of the economic instruments used by economic entities in their investment activities for the purpose of limiting, reducing or eliminating negative impact and obtaining a positive energy effect. Positive impact on the environment is ensured by optimizing production resource cycle. Identifying the need for such investments requires constant attention, since the positive and negative effects of technogenic impacts are external to the production process and are not in the focus of producers' interests.

Basic methods of scientific knowledge are widely used during the study of the nature of investing into energy saving technologies within the framework of digital economy: these are induction and deduction methods, analysis and synthesis. Summing up the results of the study on special features of environmental investment in mining enterprises and arranging proposals to improve their classification, the dialectical, logical and graphical methods were used.

The current methodologies use the cost-based principle, according to which energy efficiency improvement is reduced mainly to reducing energy consumption. At the same time, according to the author, energy efficiency is not only a production and a technological and economic process associated with reducing energy consumption and their cost. It includes also a social component. The social aspect of energy efficiency is aimed at meeting the needs of society for energy resources the way that satisfies the needs of the modern generation and does not endanger future generations in their ability to meet their needs as well. Based on the proposed methodological approach, one can say that from the point of view of financial analysis the current methodology for assessing the efficiency of investments in energy saving sector requires improvement.

That is why modernization is said to be partially paid by electricity consumers, as they will have to compensate the investment component of the tariff for quite some time. Therefore, there is a need to return part of profit obtained through the tariff increase in order to implement socially important measures: reducing electricity tariffs or investing in further energy efficiency improvements. The value of profit to be directed to realization of these goals, can be determined by the following formula:

$$
\Delta t=k \bowtie \Delta-\Delta R
$$

where $\Delta t$ is the amount of electricity tariff's reduction; $\Delta P$ is the amount of profit received from implementation of energy efficiency projects for a year; $k$ is a coefficient, which determines co-financing shares, for example, $k$ equals to 0.8 , if 80 per cent of investments are compensated due to the investment component of the tariff; $\Delta \mathrm{R}$ is the amount of energy saved over several years. 
One should remember that the current methodology for assessing efficiency of investments in energy efficiency has a number of drawbacks, namely:

- international requirements are not adapted to a variety of conditions;

- social aspects of energy efficiency improvement can not be taken into account. It requires assessment due to the use by consumers and energy generating companies of the joint investment mechanism in energy saving projects [2].

In order to eliminate these drawbacks it is necessary to update the current methodology as follows:

- first, it is necessary to calculate social effect from the introduction of energy efficient projects, aimed at reducing harmful emissions from organic fuels' combustion by establishing a regulatory benchmark to measure this social effect (average annual emissions reduction in accordance with Russia's international obligations);

- second, to identify social effect of energy saving measures by determining the part of profit that was made as a result of the introduction of measures and should be directed to reduction of electricity tariffs or investments in further energy efficiency improvements.

\section{Results}

The scientific novelty of the research is as follows:

- the author's definition of investments in energy saving sector was created, attributes and features of the stated type of investments were defined;

- features of assessment of investments in energy saving sector were highlighted, the model (formula) of return on investment costs with the help of consumers of enterprise products was defined;

- recommendations regarding improvement of the processes of investment in energy saving sector at the enterprise level and at the level of state bodies are given.

Critical analysis of the above definitions showed that the latter do not sufficiently disclose the essence of investments in energy saving sector as an economic category and do not take into account industry-specific features of investing in the energy saving sector. Thus, according to the above interpretations, the purpose of investing in energy saving technologies is to reduce destructive impact on the environment or to restore the elements of the environment while increasing energy efficiency in production processes.

At the same time, it contradicts the financial nature and economic basis of economic entities' investment activity. One of investment's fundamental principles is economic viability. That is, an important condition for the implementation of any investment is the potential economic benefit, which can be obtained in the form of increase in gross output, improvement of its quality, reduction of operating costs due to automation of production processes, saving energy resources, etc.

Critical analysis of the results of investment projects implementation in the area of energy saving by domestic enterprises showed that a specific feature of this sector of economy is that the primary goal of environmental investment is to reequip the production process and/or introduce waste processing technologies to save energy resources and cut operating costs respectively. At the same time, the object of investment in energy saving technologies is not the elements of the environment, but the production capital of the enterprise. With significant capital intensity of investments in energy saving sector, profit from their 
6

introduction is insignificant, the income is not accompanied by real cash receipts and is often estimated as prevented harm to the environment and human health, or reduced energy consumption, which has already been expected.

As a result of studying the investment practice in the energy saving sector, we consider it necessary from the financial and economic point of view to point out the following features of this type of investments:

- low attractiveness for enterprises (investors) due to low level of profitability and long payback period;

- substantial social and economic value, first of all, for society and the state;

- prevailing role of coercive factors (increased environmental taxes and fees, fines for environmental pollution and non-compliance with environmental regulations, etc.) promoting investments in energy saving sector over economic (income and profit growth, cutting expenses, etc.) and market factors (strengthening competitiveness, increasing market share, etc.));

- existence of an objective issue of complex assessment of results of implementation of investment projects in energy saving, which can be both positive and negative, and cover local, regional and national levels;

- complexity of accounting for time, risk and uncertainty due to the long-term nature of such investment projects.

In order to take into account these economic features while creating the investment policy in energy saving, and develop an effective methodological base to be able to evaluate the results of its implementation we consider it necessary to improve the concept of energy saving investments by specifying investment objects. Thus, energy saving investments include all types of property, financial, information and intellectual values invested in natural, productive and human capital of an enterprise with a view to obtaining additional economic, social and environmental benefits by reducing product life cycle greening, increasing energy and resource efficiency and ensuring environmental security. At the same time, investment activity (investment) should be considered as a set of practical actions of the subjects taking part in the investment process and all stakeholder groups (investors, providers, intermediaries, the state, territorial community, etc.) aimed at effective formation and placement of investment resources in order to obtain planned social, economic, environmental or other effects or benefits from energy conservation measures.

The main purpose of such investments is to obtain additional economic benefits by the economic entity by means of reducing emissions from pollutants into the air, reducing environmental fines and saving all types of energy resources. These investments provide also an additional effect in the form of regional ecological improvement by reducing anthropogenic load and energy intensity of the region's economy.

\section{Discussion}

The problem of implementing investments in energy saving technologies is to assess their efficiency. There are five steps that should be taken into account when assessing the efficiency of investments in energy saving:

1) saved electricity cost calculation (or other energy resources);

2) identifying the volume of investments; 
3) calculation of annual operating costs and depreciation charges;

4) identifying net profit, profitability and payback period of investments;

5) comparison of economic indicators of options selected.

Systematic development underfinancing, maintenance and renewal of energy infrastructure, in particular pipelines and electricity networks, all these lead to the current pricing on energy carriers. These are also the reasons why neither producers nor consumers have incentives to invest in energy saving projects. Current pricing practices lacking numerous government subsidies and other forms of administrative support result in most energy sectors being economically inviable.

It could be definitely proved that the revealed effects are measurable and nonmeasurable [12]. Being essential from business point of view the measurable effects include energy savings, increase in output, tax benefits, decrease in environmental compliance payments. Innovative approach considers the scheme of the financial funds, material resources and information with all of them being united in accordance of the logistical principles [10] which could be implemented to management of complex IT projects as proved by the Russian scientists [11].

\section{Conclusion}

In the course of the study, the recommendations could be as follows. In order to realize financial and economic potential of energy efficiency improvement, joint and concerted actions by the legislative and executive authorities are necessary. Quick-impact measures include activities that can be developed in less than a year and that can have a significant impact at a moderate cost. Here are some examples of such solutions: information campaign to raise awareness about energy efficiency improvement, increasing budget planning time, introducing the right to manage saved energy, as well as setting the procurement rules that encourage the use of energy-efficient technologies, reorganization of municipal heatsupplying companies into commercial enterprises or private and public partnerships.

Energy efficiency investments in enterprises in the conditions of digital economy should develop under the following conditions:

- to provide sufficient budget expenditures to use energy efficiency potential in order to improve welfare, competitiveness and reduce environmental impact;

- to ensure the long-term energy saving financing. Investments in energy saving should also be balanced between projects and their programs.

In order to develop investments in energy saving sector the authorities should do the following:

- consider energy efficiency commitments as a condition for granting licenses, tax incentives and incentives, municipal subsidies, etc.;

- use the IFIs experience in the process of developing tax policies and tax incentives for energy efficiency and renewable energy to maximize the effectiveness of any such benefit.

All these measures will lead to development of investment activities in the energy saving sector and will increase energy efficiency of individual economic entities, sectors and economy in general.

In this article the following definition of investments in energy saving sector was made: investments in energy saving sector represent investments in different modern technologies 
8

that can yield economic benefits in terms of increasing gross output, improving its quality, reducing operating costs by optimizing and saving energy resources. The most important features in terms of assessment of investments in energy saving sector are the lack of a methodological base focused exactly on energy saving investments.

In terms of investment analysis itself, energy saving projects often have long payback periods, they are very complex in terms of calculating social, public and environmental effects, and accordingly, appear to be unprofitable for enterprises. But the return on energy efficiency projects should be included in the tariff or price of the enterprise's products, which is fair from the point of view of the modern economy. On the basis thereof, the model (formula) of return on investment costs with the help of consumers of the enterprise's products is defined.

In this regard, these are the following levels of implementation of investment policy in energy saving: the level of enterprise, the level of municipal and federal authorities. For each level of implementation specific recommendations for improving investment processes in the energy saving sector are given. These recommendations can be used to design the investment policy of an enterprise, region and the country in general in the era of digital economy.

\section{References}

1. C. Cooremans, Investment in energy efficiency: do the characteristics of investments matter? Energy Efficiency, 5(4), pp. 497-518 (2012)

2. J. Jackson, Promoting energy efficiency investments with risk management decision tools, Energy Policy, 38, pp. 3865-3873 (2010)

3. A. S. Gorshkov, N. I. Vatin, P. P. Rymkevich, A. F. Mozhaysky, O. O. Kydrevich, Payback period of investments in energy saving, Magazine of Civil Engineering, 2(78), pp. 65-75 (2018)

4. T. Nehler, J. Rasmussen, How do firms consider non-energy benefits? Empirical findings on energy-efficiency investments in Swedish industry, Journal of Cleaner Production, 113, pp. 472-482 (2016)

5. E. Cagno, E. Worrell, A. Trianni, G. Pugliese, A novel approach for barriers to industrial energy efficiency, Renewable and Sustainable Energy Reviews, 19, pp. 290308 (2013)

6. Aleksandrov, M. Fedorova, MATEC, 170, $01011 \quad$ (2018). doi.org/10.1051/matecconf/201817001011.

7. K. Sawade, Technological Development of the Superconducting Magnetically Levitated Train, Japan railway engineer, 160, pp 8-4 (2015)

8. D. E. Rob, Technical and economic comparison of high-speed-rail and maglev systems, Railway Technical Review, 1, pp. 9-15 (2016)

9. O. V. Kalinina, Universal approach to building the progressive scale for income taxation, Actual Problems of Economics, 2, pp. 387-400 (2016)

10. O. Ilin, S. Kalinina, Financial logistics innovations in IT Project Management. MATEC, 193, 05062, (2018). doi.org/10.1051/matecconf/201819305062 
11. O. Kalinina, E. Balchik, S. Barykin, MATEC, 239, 04021, (2018). doi.org/10.1051/matecconf/201823904021

12. A. Mineeva, O. Lebedeva, Investment Valuation of Energy Efficiency Measures within Mining Companies, Journal of Advanced Research in Law and Economics, 2(8), 601611 (2017). 